\title{
Opportunities and Challenges Faced by Management Accounting in the Era of “Internet Plus” and Big Accounting
}

\author{
WU Mingjing \\ Wuhan Business University, Wuhan, 430056, China \\ E-mail: 1905227419@qq.com
}

Key words: Internet Plus; management accounting; opportunity; challenge

\begin{abstract}
The rapid development of Internet has created a new information era. As the product of information technology development, the Internet is a new information transfer mechanism, which solves the problem of asymmetric information by means of technology and therefore solves the problem in essence. In traditional industries, all information related parts may be replaced by the Internet, thus greatly improving efficiency. While the Internet Plus era provides good technical support and development opportunities for the development of management accounting, it has brought unprecedented challenges. This paper analyzes the opportunities and challenges brought by Internet plus for management accounting, and puts forward countermeasures to provide reference for the development of Internet Plus era management accounting.
\end{abstract}

\section{Introduction}

"Internet Plus" and the technology and ideas behind it are driving profound changes in production mode and relations. It also promotes the deep reform and leapfrogs development of the accounting profession and provides a rare opportunity for the management accounting application. The emergence of "Internet Plus" provides a new method for the information acquisition and processing of management accounting, which greatly enriches the function and efficiency of management accounting. [1] Internet applications such as cloud computing and Big Data have virtually built a digital channel between enterprises, and bring the comprehensive optimization and upgrading of management accounting which includes service model, technical innovation, data sorting and information integration.

The era of Big Data makes it possible to collect consumer preference, market trend, enterprise production and operation information, and to provide enterprises with information guarantee for their production positioning and the amount of supply determined by demand. In the Internet era, data collection is not a problem, and managers' attention is not only limited to structured data, but also to unstructured data. [2] For example, in management accounting, the learning level of balanced scorecard in performance evaluation and unstructured data processing at the customer level are easy to obtain, which is conducive to the implementation of the balanced scorecard. [3]At the same time, the practical application of statistics is counter-productive to the balanced scorecard, which benefits the development of management accounting theory.

The arrival of the "Internet Plus" era has not only changed the concept of business management but also promoted the innovation and development of management accounting. Whether it is ABC, $\mathrm{ABM}, \mathrm{ABB}$ or the comprehensive balanced scorecard, all fundamentally break through the information system that the original management accounting relies on, and attach more importance to the nature of the management accounting management and to mining enterprise business information management connotation, so as to improve the management quality of accounting information. 


\section{Deficiencies of Management Accounting in the Internet Era}

\section{Lack of emphasis on management accounting}

Accounting organizations lack emphasis on management accounting. At present, China has not established the management accounting association, and the functions of management accountant are taken by the financial accountant. [4]Secondly, enterprise management decision makers lack attention to and application of management accounting. Financial accounting focuses on providing information about the financial status, operation results and cash flow of enterprises to external stakeholders while management accounting dedicates to providing information about management planning, operation management and forecasting decisions for internal managers of enterprises. The importance business decision makers attach to management accounting directly affects the application of management accounting in enterprises. [5]The lack of understanding of management accounting in business decision makers will directly affect the application of management accounting in finance department. Most enterprises do not have the management accounting department, and therefore management accounting does not play its great role in the enterprise management. [6] Finally, accountants themselves lack attention to management accounting which is simply understood as making account. The vigorous development of the Internet has brought a series of new business such as Tencent QQ, Red Envelope and WeChat Lucky Money. If we fail to realize the importance of management accounting, we will not be able to provide accounting theory support for the new business.

\section{Advantages of practical application of Big Data without being taken}

With the advent of the information era, Big Data has been known by various enterprises and gradually adopted. However, in the practical work, how Big Data can be combined with management accounting to make the real application and further develop enterprises still remains the weak link of many enterprises. The reason is that enterprises have neither correct understanding of the specific application of Big Data, nor do they develop techniques for Big Data and management accounting applications, which leads to one-sided understanding and thus affects the overall development of enterprise operation. Particularly for the small and medium-sized enterprises whose capital cost is relatively limited, if they cannot judge the market situation correctly but blindly expand production and invest in equipment and machines, it is very detrimental to their professional production. Therefore, the practical application of management accounting under the influence of Big Data is necessary for the whole operation of enterprises. Enterprises must firstly make clear their development direction and objective, and then combine the advantages of Big Data and management accounting to guide the overall operation of enterprises, so as to make better decisions and judgments for enterprises.

\section{Most accounting personnel lack computer skills in “Internet Plus” era}

On the one hand, against the backdrop of the development of the "Internet Plus", the rapid development of information technology and the increasingly complex economic data on the market lead to the difficulty of the enterprise's financial data analysis and processing. Some enterprises in China, however, often use the most primitive and inefficient way to manually check books and input financial indicators in the process of financial data processing, which will not only affect the efficiency of enterprise financial analysis, but also cause data deviation and reduce the enterprise benefits. On the other hand, while accounting talents in China have reached saturation point, the accountants who really possess high-end computer skills are rare. With the arrival of "Internet Plus" era, the disconnection between computer science and accounting disciplines has led to the emergence of "high-end talent shortage" in management accounting. In order to adapt to the accounting informatization under the Internet era, it is necessary to strengthen computerized accounting training for accounting personnel and cultivate and forge a management team who know about both finance and business. 


\section{Relatively incomplete information security system in enterprises}

As an enterprise, clear information in real time is the key to further development. The data information with effective analysis and sorting is especially useful. The more detailed the analysis process is, the greater the possibility of practical application for enterprises. The key information includes enterprise customer information, market research and future development that are crucial for decision-making. The security management of the above-mentioned information is of great significance because once leaked to peers, the internal loss of the enterprise is undoubtedly huge.

In particular, the effective application of the Internet makes the information security management in enterprises very unfavorable, and the use of staff and other issues make it even worse. Therefore, enterprises are required to strengthen their internal management and promote the information security system, which can be attributed to the practical application of the management accounting with both excellent professional staff and conscientious work attitude in order to ensure the deep mining of enterprise information and achieve security management.

\section{Solutions for management accounting development in "Internet Plus accounting” era}

It is the influence of "Internet Plus accounting" that makes management accounting faces many opportunities and challenges. In this situation, the corresponding management measures must be taken to ensure that the management accounting really plays its role and promotes the long-term development of enterprises.

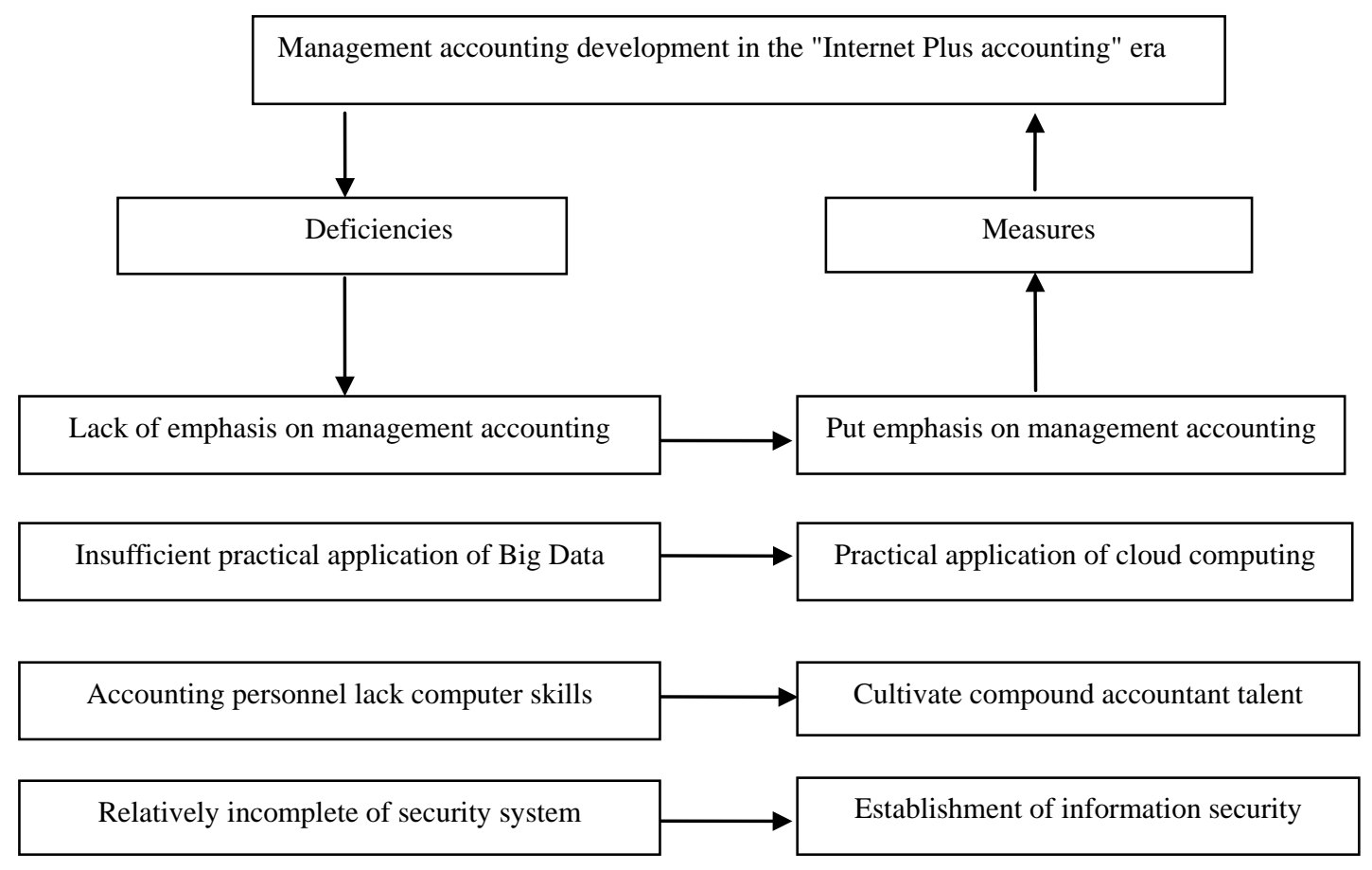

Figure1. Framework of management accounting development in the "Internet Plus accounting”era

3.1 More emphasis on management accounting and promoting management accounting by the Internet information platform

First, the accounting organization shall establish the management accounting association and strengthen international exchanges and cooperation in management accounting to actively absorb the cultural achievements of advanced management accounting abroad. Second, the enterprise management level should attach more importance to management accounting, making clear division of labor between management accounting and financial accounting. Enterprises shall have a full-time management accounting department and offer it independent functions. More emphasis should be put on typical case study as well as the relationship between theory and practice. While actively gaining experience from experienced enterprises, enterprises should also give full play to 
management accounting in enterprise management.

The compensation incentive management system is constantly improved to create a favorable environment for the development of internal management accounting. Meanwhile, enterprises should be equipped with Big Data thinking, strengthening the application and promotion of modern management tools such as financial sharing center model, cloud procurement, cloud sharing and cost management cloud services. Last, accounting personnel should integrate with the "Internet Plus" thinking and adapt to the general development direction of the industry in "Internet Plus" era.

\section{Practical application of cloud computing technology}

The practical application of cloud computing technology is the core of Big Data applications. In current information acquisition, raw data without being processed are obtained and applying them directly to the production and sales sections can be very risky because their accuracy and rationality are not guaranteed. Cloud computing technology is the process of analyzing and sorting out data, which reduces the time cost and strengthens the effective processing of data at the same time, making up for the drawback of the inaccurate data information analysis technology. Especially, the transformation of information in the cloud computing directly transfers raw data to the effective information meeting the needs of management accounting through the technical application guidance, which solves the shortage of storage space and strengthens the timeliness and accuracy of the information processing results.

\section{Improving the quality of accountants and cultivating compound accountants}

In the accounting industry under the era of "Internet Plus", the function of accounting has changed from accounting to management. On the one hand, enterprises should vigorously introduce high-end management accounting personnel. On the other hand, they should attach more importance to the transformation and cultivation of internal accounting personnel. Enterprises should make full use of the Internet and other modern media means, adopting the mode of "Internet Plus teaching" to continue the education of accounting personnel to improve their management ability and cultivate compound accountants. The accounting academic seminar should be carried out at regular intervals to constantly summarize the experience of management accounting, and improve the management ability of accounting personnel. The accounting computerization training for accountants should be strengthened to adapt to the new requirements of accounting informatization under the "Internet Plus" era. Meanwhile, accounting personnel should be encouraged to learn about new disciplines including the knowledge of internal auditing, corporate finance and other aspects to broaden their horizon. For accounting personnel, upgrading knowledge and thinking conforms to the general direction of the industry in "Internet Plus" era, and it is also the only way to increase their own value.

\section{Establishment of information security system}

As mentioned above, information security has a certain impact on the development of enterprises, so information security guarantee is very important. This requires that the enterprises must have corresponding management measures such as the excellent application of network technology and management. Once behaviors like forgery and leaks happen, they can be known in the first place so that corresponding decisions can be made. In addition, many enterprises are unable to establish their own information data processing library due to factors such as their self-development. In view of this situation, enterprises need carefully examine other companies' service level, business level and other factors, carrying on strict quality control to minimize risk.

\section{Conclusion}

To sum up, in the era of “Internet Plus”, management accounting has development opportunities and at the same time encounters major challenges. "Internet Plus" has provided a good foundation for the development of accounting management and changed the way of thinking. Facing numerous complicated data, the management accounting personnel can collect, analyze, process and utilize 
relevant data information with the help of cloud computing, which provides strong support for prediction, decision making, analysis and assessment. Big Data has promoted the development of management accounting, but enterprises, colleges and universities must identify the opportunities and challenges faced by it, actively learning Big Data and continuously adapting to the era of "Internet Plus" so as to realize the effective use of "Internet Plus" in management accounting.

\section{Acknowledgements}

In this paper, the research was sponsored by Opportunities and Challenges Faced by Management Accounting in the Era of "Internet Plus" and Big Accounting, Supported by Wuhan Business School. (Project No. 2016KY032).

\section{References}

[1]"Impact ofcultural difference:A case study of ERP introduction in China". Avison,David,Malauret,Julien. International Journal ofInformadon Management . 2007

[2] "ERP assessment of functional status in the temporal lobe: Examining spatiotemporal correlates of object recognition”. Mazerolle EL. International Journal Of Psychophysiology: Official Journal Of The International Organization Of Psychophysiology . 2007

[3] "Investigating the success of ERP systems: Case studies in three Taiwanese high-tech industries”. Chien,Shih-Wen,Tsaur-Ming. Computers in Industry . 2007

[4] Performance management: a framework for management control systems research. David Otley. Management Accountant. 1999

[5] The knowledge chain[J] . Richard A. Spinello. Business Horizons . 1998 (6)

[6] Knowledge management: a strategic agenda[J] . Paul Quintas, Paul Lefere,Geoff Jones. Long Range Planning . 1997 (3) 